\title{
Determinants of Business Entrepreneurship Success in Sudan
}

\section{Khattab I*, Ahmed SS and Mohmed Ahmed A}

Sudan Academy for Banking and Financial Science Al-gamma Street, School of Management, University of Khartoum, Sudan

\begin{abstract}
Entrepreneurs are involved into activities contributing to the development of economy of any country. They face many challenges that associated with the internal and external conditions. So the present study seeks to identify the determinants contributing to the success of entrepreneurship in Sudan. A questionnaire was collected from 62 entrepreneurs; the results show that the main determinants of entrepreneurship success in Sudan are access to finance, management abilities, government policies, and network support in addition to entrepreneurs' personality traits and attitudes. The results also show that there are different motives for starting a business but success stories of other entrepreneurs are of importance. The study recommends that these determinants of success should be considered while developing policies and strategies for promoting entrepreneurship in Sudan.
\end{abstract}

Keywords: Entrepreneurship; Determinants; Success factors; Economic development

\section{Introduction}

There is a broad consensus that entrepreneurship is one of the driving forces in the development of a market economy Nafukho, Muya. It is observed that economic downturn is always lifted by entrepreneurial activities that tend to boost the economic performance Kuratko. It is almost agreed that entrepreneurial activities that result in the creation of new innovative business deals impact positively on economic development.

In retrospect, governments became more concerned with entrepreneurship development and the value of entrepreneurship to the national economy. For example a study by Kelley et al. [1] revealed that "entrepreneurship is a catalyst of economic growth and national competitiveness". Additionally the Global Entrepreneurship Monitor (GEM) (2010 Global Report) claims that most policymakers and academics believe in the value of entrepreneurship to the society and economic growth. They are convinced that entrepreneurship can positively encourage innovation and economic reform. Similarly in Sudan, entrepreneurship has attracted the interest of the government as well as the private sector. Sudan as a least developed Sub-Saharan African country that is challenged by many development dilemmas, the country's socio-economic indicators display the poor performance; the country has experienced negative rate of economic growth, high unemployment rate and the annual inflation rose to about 550 percent in September 2016 before declining to 370 percent in January 2017 (IMF, 2016) and it ranked $171^{\text {th }}$ out of 187 according to the Human Development Index in 2016 as a result of high poverty rate, low education levels, poor health conditions and high gender inequality (UNDP, 2015). In addition to the unique context with its fragile and conflict affected regions restricting development. Sudan's low development profile has triggered the need for exceptional development efforts. Thus entrepreneurship in Sudan is deemed as an effective way out of the current economic dilemma. Accordingly several efforts were made to develop and promote entrepreneurship and to support and sustain the success of entrepreneurs. For example, following the launch of Microfinance Initiative in 2007, the government of Sudan has taken serious efforts to support entrepreneurial activities, various initiatives were kicked off some of them focused on building the individual capacity, others paid attention to institutional build up, where the government agencies get involved in mapping policies and regulations required to support entrepreneurship. Some of these efforts were explained below.
Sudan Startup Weekend programme is an example of a worldwide initiative that was followed in Sudan, where all potential entrepreneurs come together for weekend long workshops to pitch ideas, form teams, and start their business. Teams organically form around the top ideas (as determined by popular vote) and then it's a 54 hour work that ends with business model creation, coding, designing, and market validation. The weekends conclude with presentations in front of local entrepreneurial leaders with another opportunity for critical feedback.

Mashrouy programme is another effort executed to promote entrepreneurship in Sudan. The Young Businessmen's Association in partnership with the British Council and the British embassy has launched a competition that aims to discover the entrepreneurial abilities of youth in Sudan. The completion is run for the fourth time consequently and it provides entrepreneurship training for hundreds of young potential and existing entrepreneurs.

$B A D E E R$ is an example for building the individual capacity, it is a part of a collaborative partnership between Sudani telecommunication company and Riyadah Training Center that aim to train 1000 young male and female on entrepreneurship.

IRADA Company: The Islamic development Bank and Bank $\mathrm{Al}$ Khartoum have partnered together to establish IRADA company as an Islamic Microfinance Institute on 2012. IRADA distinguishes itself from other microfinance institutions by providing finance and technical support for its beneficiaries. IRADA seeks to support smes development through extending its support beyond the finance element. For example in the Moringa and Jatropha Agricultural Project, IRADA has managed to empower 150 family in traditional agricultural sector by providing technical and supervisory support in addition to finance.

For the Institutional build up: In a bid to provide institutional

*Corresponding author: Khattab I, Sudan Academy for Banking and Financial Science Al-gamma Street, School of Management, University of Khartoum, Sudan, Tel: 24992079 0284; E-mail: iadlan@yahoo.co.uk

Recieved August 10, 2017; Accepted October 04, 2017; Published October 11, 2017

Citation: Khattab I, Ahmed SS, Mohmed Ahmed A (2017) Determinants of Business Entrepreneurship Success in Sudan. J Entrepren Organiz Manag 6: 218. doi: 10.4172/2169-026X.1000218

Copyright: @ 2017 Khattab I, et al. This is an open-access article distributed under the terms of the Creative Commons Attribution License, which permits unrestricted use, distribution, and reproduction in any medium, provided the original author and source are credited. 
support for the development of entrepreneurship, several bodies such as Academic Institutions and Banks, for example, the Family bank and other Microfinance Institutions have established Entrepreneurship Development Centres that seek to provide microfinance receivers with practical training and hands on experience to start up business. Examples of these centres: Sudanese Ryadah Centre, Sudanese Eibdah Centre, etc.

Entrepreneurship education programmes additionally, some universities and educational institutions in Sudan have introduced Entrepreneurship module as a compulsory course within their curriculum. For example, Khartoum University and Ahfad University. Where Alryadah College has developed a leading degree program in Entrepreneurship.

In relation to Government agencies effort many initiatives were undertaken, for example: The ministry of higher education and scientific research in collaboration with the ministry of industry have organized a forum to raise general awareness about entrepreneurship, and to attract ministers and policy makers' attention to the value of entrepreneurship in providing economic solutions, the forum took place at the ministry board. Additionally on several occasions the minster of higher education and scientific research has conducted round table discussions for local and international entrepreneurship academic experts. Several recommendations where further pursued.

Despite various efforts undertaken to promote entrepreneurship in Sudan and ease the obstacles facing entrepreneurs in Sudan, but it appears that entrepreneurs as others in many countries still face set of obstacles related to production, marketing, infrastructure, financing and policies that support entrepreneurship (Ref Ganga). Additionally, very few studies investigated determinants leading to the success of entrepreneurship in Sudan.

Thus the main objective of this study is to explore the various factors affecting the success of entrepreneurship in Sudan.

This paper is structured as follows: Following this introduction, Section 2 contains a concise review of the literature, and the identified success factors. Section 3, contains the methodology and data description. And in section 4, the results and discussion is presented. We conclude by section 5 .

\section{Literature Review}

There is a little agreement on the definition of business success [2]. Fuller et al. [3] argued that small entrepreneur's success should be measured by its positive contribution to the community in comparison to not establishing the enterprise at all. Lussier and Pfiefer [4] and Stefanovic et al. [2] define success as the business ability to survive.

Some researchers categorized determinants of entrepreneurs' success into three main groups: (a) the psychological elements and personality traits of the entrepreneurs, (b) the managerial skills and training of the entrepreneurs and (c) the external environment in which the enterprise operate [5]. Others combined the importance of personality traits to the need for experience, training and managerial skills for the entrepreneurs to achieve business success [6]. The environmental factors are the third determinants of business success and it includes satisfactory government support, ease of getting finance and the support of family and friends [5] Green and Pryde, and Pratt summarized the determinants that leads to business success; on the ability of the entrepreneurs to take initiatives, get support by his network, environmental factors and third party assistance $[7,8]$ argued that entrepreneurs' previous experience, interpersonal skills, access to capital, hard work are important drivers serve as the success of any organization. Experience and knowledge of the local market also plays a great role in the success of entrepreneurs [9] Whereas, Eroglu and Picak [10] related the success of entrepreneurs' to national cultural attributes. Moraima De Hoyos-Ruperto (2013) argue that systematic factors such as education and mindset in addition to individual factors associated with social competences affect the entrepreneur's networking activities which ultimately influence the success of the entrepreneur.

On the other side, some scholars chose to investigate failure determinants that hinder the development of entrepreneurship [5] found that unstable political and economic environment, complex taxation, corruption, and poor law and order situation are common problems faced by the developing countries. According to Hussain et al. [11] lack of financial assistance and the difficulty to access capital are most critical environmental failure factors. Others stated that poor infrastructure is a very influential factor in the failure of entrepreneurship [12], additionally, Santhi and Rajesh [13] found that most of the challenges that face entrepreneurs in India are related to polices and social challenges.

Building on this review, the above studies provide the ground for this paper, it appears that there is a need to investigate entrepreneurship status quo in Sudan and identify factors that affect the success of entrepreneurship in Sudan.

\section{Research Methodology}

This is an exploratory study that seeks to explore the factors determining the success of entrepreneurship in Sudan, and the data collection method used was a questionnaire directed to entrepreneurs in some states in Sudan. At this stage, it seems opportune to clarify that the responses resulted from a convenience sample, which involved a total of sixty two questionnaires. Since there is no information about the number of entrepreneurs in Sudan and there is no any approved list of entrepreneurs in Sudan, researchers chose to use applicants of one of the most powerful and popular entrepreneurship initiatives' programmes in Sudan, that is Mashrouy competition. A total of 100 questionnaires were distributed amongst the Mashrouy applicants, only 62 were found ready for analysis. Regardless of the low number of questionnaires and the reason of convenience, it should be noted that researchers tried to elicit the questionnaire with respondents from broad geographical area and from different entrepreneurial activities. Also, we did not investigate possible correlations between variables. While this may be seen as a limitation, it seems important to emphasize that this position, together with the fact that our study was an exploratory analysis [14] allowed us to collect, confront, and manage different opinions from entrepreneurs in Sudan. Following the guidelines proposed by Hill [15] our questionnaire was tested before being administered to the respondents and it composes of four parts. The first part covers the demographic information about respondents, the second section includes information about the entrepreneurs' management abilities, the third section covers the external factors and the final set of questions covers the entrepreneurs' personality traits and attitudes. A Likert-type scale was used to measure each of the success variables within the construct for this study. In addition to the scales, open ended and multiple choice questions were asked to provide more personal feedback from respondents.

\section{Empirical Results and Analysis}

In this section we present the results of the questionnaire and the analysis of these findings. 


\section{Participants' profile}

The first part of the questionnaire collected general information about the entrepreneurs i.e., gender, level of education, business geographical location and the type of the business, and the age of the business. Among the 62 entrepreneurs, 43 of them were males and 19 were females as shown in Table 1 . The results also showed that $58 \%$ of participants have a bachelor degree. Most of those who participated in this investigation were from Khartoum state (59\%) whereas the rest from various other states in Sudan. It appears that entrepreneurs where mainly working in the service (37\%) and manufacturing sector (33\%). The result shows that $56 \%$ of participants questioned in this investigation established their business for less than three years. Interestingly $(61 \%)$ of those questioned had a previous experience in running their business.

\section{Motivation for starting the business}

Table 2 presents the main results with respect to the motives behind establishing the business. It appears from the result that entrepreneurs have different motives that urge them to start their own business. $22 \%$ were inspired by the success stories from other entrepreneurs. Additionally, participants relate their willingness to start up their business due to the frustration in finding jobs (14.5\%). Participants also deem the desire to be self-employed as one of the motives to start their

\begin{tabular}{|l|c|c|}
\hline \multicolumn{1}{|c|}{ Characteristics } & Frequency (\%) & Percentage \% \\
\hline Gender & 43 & 69 \\
\hline Male & 19 & 30 \\
\hline Female & \multicolumn{2}{|l|}{} \\
\hline Level of education & 12 & 19 \\
\hline Secondary/Vocational/Diploma & 36 & 58 \\
\hline Bachelor degree & 14 & 22 \\
\hline Postgraduate qualification & & \\
\hline Location of business & 37 & 59 \\
\hline Khartoum State & 25 & 40 \\
\hline Other State & 21 & 33 \\
\hline Type of business & 23 & 37 \\
\hline Service & 13 & 20 \\
\hline Manufacturing & 5 & 8 \\
\hline Retail & & \\
\hline Other & 35 & 56 \\
\hline Age of firm & 13 & 20 \\
\hline Less than 3 & 10 & 16 \\
\hline More than 3 less than 5 & 4 & 6 \\
\hline More than 5 less than 7 & 39 & \\
\hline More than 7 & 24 & \\
\hline Experience of any other business before & & \\
\hline Yes & & \\
\hline No & & \\
\hline & & \\
\hline
\end{tabular}

Table 1: Illustrates the respondents' demographic profile.

\begin{tabular}{|l|c|c|c|}
\hline Motivational factors influencing the idea & Frequency & $\begin{array}{c}\text { Percentage } \\
\%\end{array}$ & SD \\
\hline $\begin{array}{l}\text { To satisfy basic needs and to gain } \\
\text { independent living }\end{array}$ & 8 & 12.9 & 1.01 \\
\hline Frustration due to unemployment & 9 & 14.5 & 1.1 \\
\hline An ambition to gain Social Status & 7 & 11.2 & 0.88 \\
\hline To have Self Employment & 12 & 19.3 & 1.5 \\
\hline Dissatisfaction in previous Job & 6 & 9.6 & 0.75 \\
\hline Success stories of entrepreneurs & 14 & 22.5 & 1.76 \\
\hline Family business & 6 & 9.6 & 0.75 \\
\hline
\end{tabular}

Table 2: Motivation for starting the business. business (19.3\%). Participants were found to have different reasons to start up business such as to satisfy their basic needs (12.9\%), and the desire to secure social status (11.2\%), or dissatisfaction in previous jobs (9.6\%). Responses related to satisfying basic needs and being selfemployed corresponds with the Sudan context as a developing country, that has high rate of unemployment and high poverty rate (IMF,2016), where most of the people may have to innovate and set their own business to satisfy their needs and ambitions.

According to the participants the main motive to start their business is related to the success stories from other entrepreneurs. Perhaps this is related to the collectivism nature of the Sudanese society where individuals are influenced by their community. Especially that $61 \%$ of participants had previous experience in setting their business, so they are not far from entrepreneurs' community. The importance of collectivism and the business start-up coincides with some scholars views' who deem that collectivism attributes provides a protective environment that minimizes the uncertainty associated with business creation and innovation implementation [16]. Additionally, Gelfand et al. [17] argue that collectivistic orientation encourage entrepreneurial activities and fosters commitment among business community groups. Additionally, the findings that socio-cultural values are main aspect of the entrepreneurial environment $[18,19]$. As for the responses related to self-employment and frustration of being unemployed.

\section{Management abilities}

Participants appeared to be aware of basic management skills that are required to run their own business. Their score is high at all management abilities components, which imply that management skills are required for entrepreneurship success. The results also showed that $79 \%$ around 50 participants of entrepreneurs regularly attend training programmes to enhance their management abilities. $64 \%$ of entrepreneurs believe that they know their customers and their needs. Respondents appear to have good management awareness and understanding of market needs (Table 3 ).

Interestingly, components of the management abilities named in our instrument: efficient administration of financial records, financial planning and budgeting and marketing are the most critical to the success of entrepreneurship [20]. The good awareness of respondents on management issues may be attributed to efforts and initiatives discussed earlier and undertaken by different organizations and training centers that regularly seek to build individual capacity. The offered and available training may have helped respondents to develop their management skills, though clearly they vastly vary in their education backgrounds.

\section{External factors}

Participants appeared to be aware of the importance of external factors to the success of entrepreneurship, but they were unsatisfied about government policies (41 participants) that support entrepreneurship development. They also believe that market structure and competition is not supporting their entrepreneurial activities. Respondents also recognize that for successful entrepreneurial activities they need finance and capital access to start up their business (62\%) and to sustain it (This conforms to several studies around the world that have been carried out to throw light on the challenges faced by entrepreneurs. For example, in South Asia, lack of access to capital has been a primary obstacle for entrepreneurs, and recent research suggests it continues to be" [21] Additionally, Fereidouni et al. [22] found that business environment including government policies, access to finance is a very critical factor for entrepreneurship success. 
Citation: Khattab I, Ahmed SS, Mohmed Ahmed A (2017) Determinants of Business Entrepreneurship Success in Sudan. J Entrepren Organiz Manag 6: 218. doi: 10.4172/2169-026X.1000218

Page 4 of 5

\begin{tabular}{|c|c|c|c|c|c|}
\hline \multirow[t]{2}{*}{ Management abilities } & \multicolumn{2}{|c|}{ Frequency (\%) } & \multicolumn{3}{|c|}{ Percentage (\%) } \\
\hline & \multicolumn{2}{|c|}{ Yes } & \multicolumn{3}{|c|}{ No } \\
\hline Do have a business plan & \multicolumn{2}{|c|}{$52(83)$} & \multicolumn{3}{|c|}{$10(16)$} \\
\hline Do you use an expert to develop a business feasibility study & \multicolumn{2}{|c|}{$31(50)$} & \multicolumn{3}{|c|}{$32(51)$} \\
\hline Do you have a formal management training & \multicolumn{2}{|c|}{$40(64)$} & \multicolumn{3}{|c|}{$22(35)$} \\
\hline Do you have a formal training in financial and marketing management & \multicolumn{2}{|c|}{$36(58)$} & \multicolumn{3}{|c|}{$27(43)$} \\
\hline Do you keep a record of all your business transactions & \multicolumn{2}{|c|}{$42(67)$} & \multicolumn{3}{|c|}{$20(32)$} \\
\hline Do you prepare income statements for your business & \multicolumn{2}{|c|}{$49(79)$} & \multicolumn{3}{|c|}{$13(20)$} \\
\hline Do you keep a balance sheet statement & \multicolumn{2}{|c|}{$46(74)$} & \multicolumn{3}{|c|}{$16(25)$} \\
\hline Do you keep a cash flow statement & \multicolumn{2}{|c|}{$46(74)$} & \multicolumn{3}{|c|}{$16(25)$} \\
\hline \multirow[t]{2}{*}{ To what extent do you know your customers and their needs } & Greater extent & Great extent & neutral & Less extent & No extent \\
\hline & 28 & 22 & 5 & 5 & 2 \\
\hline \multirow[t]{2}{*}{ How often do you attend entrepreneurship training } & Very often & Often & Neutral & Rare & Very rare \\
\hline & 29 & 20 & 3 & 6 & 4 \\
\hline
\end{tabular}

Table 3: Showing the management abilities.

\begin{tabular}{|c|c|c|c|c|c|}
\hline Government Policies & Percentage \% & Percentage \% & Percentage \% & Percentage \% & Percentage \% \\
\hline & Strongly agree & Agree & Neutral & Disagree & $\begin{array}{l}\text { Strongly } \\
\text { Disagree }\end{array}$ \\
\hline To what extent are the current government policies support the success of your business & 16.1 & 14.5 & 3.2 & 33.8 & 32.2 \\
\hline Competing in the current market or environment support the success of your business & 14.5 & 11.2 & 4.8 & 33.8 & 35.4 \\
\hline \multicolumn{6}{|l|}{ Financial Issues } \\
\hline The importance of finance to the start-up of your business & 30 & 32 & 15 & 31 & 25 \\
\hline To what extent it is easy to access finance for your business & 15 & 6 & 1 & 46 & 37 \\
\hline \multicolumn{6}{|l|}{ Network support } \\
\hline How strong is your relationship with supplier is important to your business success & 41 & 38 & 3 & 9 & 6 \\
\hline How strong is your customers' relationship is important to your business success & 48 & 35 & 12 & 3 & 0 \\
\hline To what extent is your relationship with your bank is important to your business success & 53 & 24 & 11 & 8 & 3 \\
\hline $\begin{array}{l}\text { To what extent is your relationship with relevant businesses is important to your business } \\
\text { success }\end{array}$ & 48 & 35 & 4 & 8 & 3 \\
\hline
\end{tabular}

Table 4: External factors influencing entrepreneurship success.

\begin{tabular}{|c|c|c|c|c|c|c|}
\hline Personal & Good & & Fair & & Poor & \\
\hline \multicolumn{7}{|l|}{ Traits } \\
\hline & Frequency & Percentage & Frequency & Percentage & Frequency & Percentage \\
\hline Self confidence & 42 & 67 & 13 & 20 & 7 & 11 \\
\hline Initiative & 42 & 67 & 14 & 22 & 6 & 9 \\
\hline Need for independence & 28 & 45 & 26 & 41 & 8 & 12 \\
\hline Tolerance for uncertainty & 39 & 62 & 21 & 33 & 10 & 16 \\
\hline Optimism & 31 & 50 & 21 & 33 & 10 & 16 \\
\hline Innovativeness \& creativity & 46 & 74 & 10 & 16 & 46 & 74 \\
\hline \multicolumn{7}{|l|}{ Attitude } \\
\hline Long term commitment in business & 40 & 64 & 12 & 19 & 10 & 16 \\
\hline Persistence in problem solving & 45 & 72 & 12 & 19 & 5 & 8 \\
\hline Attitude to risk taking & 36 & & 19 & 30 & 7 & 11 \\
\hline Capability of dealing with failure & 46 & 74 & 13 & 20 & 3 & 4 \\
\hline Use of feedback & 42 & 67 & 11 & 17 & 9 & 14 \\
\hline Seeking help and advice & 39 & 62 & 18 & 29 & 5 & 8 \\
\hline Flexibility & 41 & 66 & 16 & 25 & 5 & 8 \\
\hline Need for achievement & 40 & 64 & 15 & 24 & 7 & 11 \\
\hline Profit orientations & 42 & 67 & 10 & 16 & 7 & 11 \\
\hline Integrity & 37 & 59 & 21 & 33 & 4 & 6 \\
\hline Foresightedness' & 32 & 51 & 25 & 40 & 5 & 8 \\
\hline Decisiveness & 31 & 50 & 22 & 35 & 9 & 14 \\
\hline Competitiveness & 37 & 59 & 19 & 30 & 6 & 25 \\
\hline
\end{tabular}

Table 5: Agreement to the importance of personal characteristics and attitude as driving energy for entrepreneurship success.

As for the network, it appeared that participants appreciate the importance of networking for their entrepreneurship success; they perceive their relationship with the bank is the influential in their network (77\%). They also valued other relationship with suppliers (79\%), customers (83\%) and other relevant business (83\%) (Table 4). This result corresponds with other studies, where Shariff and Saud 
[23] observed that networking is very important for the success of entrepreneurs in Indonesia [24] found that networking is strongly needed to develop entrepreneurial capabilities since networking enhances learning. Besides learning, the entrepreneurs need to allow ongoing channels of communications with networks including individuals and other organizations from within and outside their business. Such networking activity is required to obtain information, raw materials, technology, knowledge, finance in order to survive. The utilization of network resources will affect the start-up of growth and latter stages of enterprises [25].

\section{Personal characteristics and attitudes}

Respondents confirmed that entrepreneurs should have personality in order to be successful entrepreneurs. They valued traits such as innovation and creativity (74\%) and self-confidence (67\%). According to participants, entrepreneurs are distinguished with certain attitudes such as capabilities to deal with failure (74\%), profit orientation (67\%) and persistence in solving problems (72\%). This result is consistent with previous research, where successful entrepreneurs must poses certain characteristics and qualities especially in decision making [26]. Other scholars identified innovation as a critical feature for the success of entrepreneur [27-29]. Many others deemed self-confidence, good communication, risk taking as essential factors for business success [30,31]. Other characteristics of successful entrepreneurs include high self-efficacy, opportunity recognition, perseverance and social skills [19] (Table 5).

\section{Conclusion and Future Research}

The present study has been an explorative one. It has tried to explore the variables contributing to the success of entrepreneurs in Sudan. The study found that finance is critical for the success of entrepreneurship business. Other aspects related to management abilities and government policies, and networks also contribute to the success of entrepreneurship in Sudan. The study also found that entrepreneur's traits and attitudes influence the success of the business.

The study suggests that there is a need for a continuous and coherent focus on financing, and proper policy mix towards promoting entrepreneurship. The main stakeholders should work together with the government to improve the internal and external conditions for entrepreneurs. Future research should seek to investigate other factors that determine the success of entrepreneurship in Sudan. Longitudinal study will provide a clearer picture of the antecedent's influence on entrepreneurial success. Also a study that investigates the obstacles and triggers for specific gender or certain sector may assist various actors to focus their efforts on the growth and success factors of entrepreneurship in Sudan.

\section{References}

1. Kelley D, Bosma NS, Amorós JE (2010) Global Entrepreneurship Monitor 2010 Executive Report, 16. Global Entrepreneurship Research Association.

2. Stefanovic I, Prokic S, Rankovic L (2010) Motivational and Success Factors of Entrepreneurs: The Evidence from a Developing Country. Journal of Economic Literature 28: 251-269.

3. Fuller TK, Mech LD, Fitts-Cochran J (2003) Wolf Population Dynamics. University of Chicago Press, Chicago, Illinois, USA, pp: 161-191.

4. Lussier RN, Feifer SP (2001) A cross national prediction model for business success. Journal of Small Business Management 39: 228-239.

5. Benzing C, Chu HM, Kara O (2009) Entrepreneurs in Turkey: a factor analysis of motivations, success factors, and problems. Journal of Small Business Management 47: 58-91.
6. Rauch A, Frese M (2000) Psychological approaches to entrepreneurial success: A general model and an overview of findings. In: Cooper $C L$, Robertson IT editors. International Review of Industrial and Organizational Psychology, 2000. Wiley, Chic ester, UK, pp: 101-142.

7. Green S, Pryde P (1989) Black entrepreneurship in America. New Brunswick NJ: Transaction Publishers.

8. Pratt V (2001) Sharing business skills in Kenya. Center for International Private Enterprise Washington.

9. Hussain D, Windsperger $\mathrm{J}$ (2010) Multi-unit ownership strategy in franchising Development of an integrated model. Journal of Marketing Channels 17: 3-31.

10. Eroglu O, Picak M (2011) Entrepreneurship National Culture and Turkey. International Journal of Business and Social Science 2: 146-151.

11. Hussain I, Si S, Xie XM, Wang L (2010) Comparative Study on Impact of Internal and External CFFs on SMEs. Journal of Small Business and Entrepreneurship 23: $637-648$.

12. Syed Wajahat Hussain Naqvi (2011) Critical Success and Failure Factors of Entrepreneurial Organizations: Study of SMEs in Bahawalpur. Journal of Public Administration and Governance 1: 17-22.

13. Santhi N, Rajesh KS (2011) Entrepreneurship Challenges and Opportunities in India. Bonfring International Journal of Industrial Engineering and Management Science 1: 14-16.

14. Yin RK (1994) Case Study Research: Design and methods, (2 ${ }^{\text {nd }}$ edn.) Thousand Oaks: CA: Sage Publications.

15. Hill LB (2006) Illusions of rationality confound creative potential. Intercultural Communication Studies 15: 77-88.

16. Stewart A (1989) Team Entrepreneurship. Newbury Park, CA.

17. Gelfand MJ, Bhawuk DP, Hishi LH, Bechtold DJ (2004) Individualism and collectivism.

18. Shapero A, Sokol L (1982) the social dimension of entrepreneurship. In: Kent CA, Sexton DL, Vesper KH editors. Encyclopedia of Entrepreneurship, pp: $72-90$.

19. Markman GD, Baron RA (2003) Person-entrepreneurship fit: Why some people are more successful as entrepreneurs than others. Human Resource Management Review, pp: 281-301.

20. Huck JF, Thaddeus M (1991) Competencies Needed for Small Business Success: Perceptions of Jamaican Entrepreneurs. Journal of Small Business Management 29: 90-93.

21. Gundry L, Ben-Yoseph M, Posig M (2002) The status of women's entrepreneurship: pathways to future entrepreneurship development and education. New England Journal of Entrepreneurship 5: 39-50.

22. Fereidouni GH, Masron TA, Nikbin D, Ekhtiari AR (2010) Consequences of external environment on entrepreneurial motivation in Iran. Asian Academy of Management Journal 15: 175-196.

23. Shariff NM, Saud MB (2009). An attitude approach to the prediction of entrepreneurship on students at institution of higher learning in Malaysia International Journal of Business and Management 4: 129-134.

24. Welpe I, Grichnik D (2006) 'Das Wissenschaftsgebiet der Entrepreneuria Finance-eine Bestandsaufnahme in Forschung und Lehre', ZfKE, 54:141-165.

25. Hatala J (2007) Assessing Social Capital Capacity: The Development of a Network Accessibility Scale, Louisiana State University 22: 53-68.

26. Say JB (1971) A treatise on political economy or the distribution and consumption of wealth. New York: Kelly AM Publishers.

27. Drucker PF (1985) "The Practice of Entrepreneurship", Innovation and Entrepreneurship Practice and Principles, Harper \& Row, New York, pp: 141-188.

28. Timmons JA (1989) The Entrepreneurial Mind, Andover, Mass, Brick House Publishing.

29. Granger MM, Sterling TM (2012) Fashion Entrepreneurship: Retail Business Planning (2nd edn.), USA: Fairchild Publications, Inc.

30. De Hoyos-Ruperto M, Romaguera JM, Carlsson B, Perelli S (2012) Entrepreneurial Environment Dilemma in Puerto Rico: A Challenge of Self and System. Journal of Marketing Development and Competitiveness 6: 11-28.

31. Cooper AC (1973) "Technical Entrepreneurship: What Do We Know?" Research and Development Management 3: 3-18. 